measures, and one would like to know how the results might have been affected by including them.

Samuel B. Guze

Department of Psychiatry,

Washington University School of Medicine,

St Louis, Missouri, USA

\section{CHEAPER CARE OF PARASUICIDES}

DEAR SIR,

The paper by Newson-Smith and Hirsch (Journal, April 1979, 134, 335-42) appears to show that social workers can be about as effective as psychiatrists in screening parasuicides, and closely follows reports by Gardner and others $(1977,1978)$ that briefly trained house physicians can also match psychiatrists in this endeavour. Does this mean that special psychiatric services of the kind originally recommended in the Hill Report (Central Health Services Council, 1962) and developed in Regional Poisoning Treatment Centres are expensive luxuries?

We wish to draw attention to the fact that psychiatrists in Charing Cross Hospital and in Cambridge, who were emulated so well by social workers or house physicians, were very generous in their offers of further psychiatric treatment and did not leave much margin for error.

Psychiatric (and social work) after-care recommended for parasuicides by psychiatrists

\begin{tabular}{|c|c|c|c|}
\hline & $\begin{array}{c}\% \\
\text { In- } \\
\text { patient }\end{array}$ & $\begin{array}{c}\% \\
\text { Out- } \\
\text { patient } \\
\text { (social } \\
\text { worker } \\
\text { only) }\end{array}$ & $\begin{array}{l}\% \\
\text { None }\end{array}$ \\
\hline $\begin{array}{l}\text { Cambridge } \\
\text { (Gardner et al, } \\
\text { 1978) }\end{array}$ & 20 & $49 \quad(8)$ & 31 \\
\hline $\begin{array}{l}\text { Charing Cross Hospital } \\
\text { (Newson-Smith and } \\
\text { Hirsch, 1979) }\end{array}$ & 27 & $65(13)$ & 8 \\
\hline $\begin{array}{l}\text { Edinburgh R.P.T.C. } \\
\text { (unpublished report, } \\
\text { 1977) }\end{array}$ & 10 & $32(14)$ & 58 \\
\hline
\end{tabular}

Compared with psychiatrists at the Edinburgh Regional Poisoning Treatment Centre (R.P.T.C.) they recommended twice as many patients for inpatient psychiatric treatment and twice as many for out-patient follow-up. It is very unlikely that these large differences in the utilization of expensive psychiatric resources can be explained by differences in the patient populations. Where is the saving?

It seems that the psychiatric services for parasuicides in these other centres largely depend on junior psychiatrists, who share out the work and have other commitments, and therefore have diluted experience and supervision. In Edinburgh most parasuicides are also assessed by a junior psychiatrist, but he has a major commitment to the R.P.T.C. for six months, where he is trained and supervised by two consultant psychiatrists who have a special interest in this area. They have learnt over the years to be much more selective and sparing in the use of psychiatric after-care for their annual 2,000 patients, most of whom are not mentally ill. Meanwhile, the repetition rate has not increased.

If less experienced colleagues refer on $60-80$ per cent of parasuicides, the psychiatrist might as well see them all in the first place. The Edinburgh model may be cheaper.

University Department of Psychiatry,

Peter Kennedy

IAN OSWALD

Edinburgh

\section{References}

Gardner, R., Hanka, R., O'Brien, V. C., Page, A. J. F. \& REEs, R. (1977) Psychological and social evaluation in cases of deliberate self-poisoning admitted to a general hospital. British Medical Journal, ii, 1567-70.

- Evison, B., Mountrord, P. M., O'Brien, V. C. \& Roberts, S. J. (1978) Consultation-liaison scheme for self-poisoned patients in a general hospital. British Medical Journal, ii, 1392-4.

Central Health Services Council (1962) Emergency Treatment in Hospital in Cases of Acute Poisoning. London: H.M.S.O.

\section{A CONTAGION HYPOTHESIS}

DeAr Sir,

This brief report of a small explorative study may be of interest. A simple socio-metric method was used to determine whether the high prevalence of reported emotional disturbance in an all-female student hall of residence was to some extent the result of case-to-case spread.

Nearly 90 per cent of the 155 residents returned a questionnaire and 23 per cent of respondents answered in the affirmative to the question 'Have you been emotionally disturbed or nervously unwell since the beginning of term?' (Two large psychiatric morbidity surveys in the same university had shown that a positive answer to this question was highly correlated with medically detected psychiatric morbidity and poor academic performance). The students were 